\begin{tabular}{|c|c|c|c|}
\hline \multirow{3}{*}{$\begin{array}{r}\text { Case Reports in } \\
\text { Gastroenterology }\end{array}$} & \multirow{2}{*}{\multicolumn{2}{|c|}{ Case Rep Gastroenterol 2017;11:599-602 }} & \multirow[b]{3}{*}{$\begin{array}{l}\text { Karger } \\
\text { Open aiccess }\end{array}$} \\
\hline & & & \\
\hline & $\begin{array}{l}\text { DOI: 10.1159/000480074 } \\
\text { Publisned online: Uctober 6, } 2017\end{array}$ & $\begin{array}{l}\text { The Author(s) } \\
\text { Published by S. Karger AG, Basel } \\
\text { www.karger.com/crg }\end{array}$ & \\
\hline & $\begin{array}{l}\text { This article is licensed under the } \\
\text { International License (CC BY-NC) } \\
\text { Usage and distribution for commer }\end{array}$ & $\begin{array}{l}\text { mons Attribution-NonCommercial } 4.0 \\
\text { rger.com/Services/OpenAccessLicense). } \\
\text { quires written permission. }\end{array}$ & \\
\hline
\end{tabular}

\title{
Postpolypectomy Intramural Colonic Hematoma: The Conservative Management of a Potentially Fatal Complication
}

\author{
Ravinder Mankoo Vanessa Kuwajima \\ University of Missouri School of Medicine, Columbia, MO, USA
}

Keywords

Hematoma · Postpolypectomy · Complication · Colonoscopy

\begin{abstract}
Most medical professionals consider colonoscopy to be a safe procedure with a low rate of severe complications such as bowel perforation, gastrointestinal tract bleeding, or mortality. Bowel wall hematoma is a rare complication associated with colonoscopy that can result in significant morbidity and even mortality. We present a case of postpolypectomy hematoma diagnosed with $\mathrm{CT}$ imaging and successfully managed in a conservative fashion.
\end{abstract}

(C) 2017 The Author(s)

Published by S. Karger AG, Basel

\section{Introduction}

Colonoscopy is a relatively safe procedure with reported rates of iatrogenic bowel perforation ranging from $<1$ to $3 \%$, iatrogenic bleeding $<0.3$ to $1 \%$, and overall mortality of $<0.7 \%$ [1-4]. Bowel wall hematoma is a known, but very rare, complication of colonoscopy often secondary to blunt trauma from the endoscope, exacerbated by underlying coagulopathies or anticoagulation therapy [5]. Patients with a bowel wall hematoma typically present with abdominal pain, rectal bleeding or hemodynamic instability within $48 \mathrm{~h}$ of colonoscopy [6]. Intracolonic bleeding is more common than extracolonic bleeding, pericolonic bleeding, 


\section{Case Reports in Gastroenterology}

Case Rep Gastroenterol 2017;11:599-602 DOI: $10.1159 / 000480074$

(C) 2017 The Author(s). Published by S. Karger AG, Basel www.karger.com/crg

Mankoo and Kuwajima: Postpolypectomy Intramural Colonic Hematoma: The Conservative Management of a Potentially Fatal Complication

or intramural bleeding, and while most episodes are relatively benign, some bleeding events can be fatal $[6,7]$.

\section{Case Report}

A 77-year-old Caucasian female with ulcerative colitis, diverticulosis, and liver cysts underwent elective surveillance colonoscopy. Two $<1 \mathrm{~cm}$ cecal polyps were removed using cold snare with subsequent placement of 3 hemostasis clips. Four 2- to 4-mm ascending colon polyps were removed using cold biopsy forceps. A sessile 1-cm transverse colon polyp was raised with injection of normal saline and removed using cold snare (Fig. 2) with the subsequent placement of 2 hemostasis clips. The colon was fixed and tortuous; however, the mucosa was normal except for mild erythema of the ascending colon and rectum without ulceration, and moderate pan-colonic diverticulosis. Following the procedure, the patient experienced sharp, left-lower quadrant abdominal pain. She was directed to the Emergency Department for further evaluation. An abdominal CT scan showed a new $1.8 \mathrm{~cm} \times 2.9 \mathrm{~cm}$ fluid collection between the inferior pole of the spleen and the splenic flexure without contrast extravasation or abdominal free air (Fig. 1), suggestive of a bowel wall hematoma. Vital signs were stable and initial lab results, including hemoglobin, were normal. The patient was admitted for close hemodynamic monitoring and pain management. She was discharged home the following day, and at outpatient follow-up 2 weeks later she was completely painfree. Repeat abdominal CT 4 months later showed complete resolution of the bowel wall hematoma.

\section{Discussion}

While complications associated with colonoscopy are rare and generally benign, there are certain complications, particularly those associated with polypectomy, that can be fatal [5]. Relatively minor complications include abdominal pain, bloating, diarrhea, nausea, selflimited gastrointestinal bleeding and side effects of pharmacologic sedation. More severe complications include colon perforation, high-volume gastrointestinal bleeding, diverticulitis and postpolypectomy syndrome [5]. A much more rare complication of colonoscopy is bowel wall hematoma [8]. Typical presenting symptoms are similar to those of other postcolonoscopy complications, including abdominal pain and gastrointestinal bleeding, making this potentially fatal complication difficult to diagnose. Prior studies have suggested that CT scan is the most effective way to diagnose postcolonoscopy complications including perforation or bowel wall hematoma [6]. This case highlights how a potentially fatal postpolypectomy bowel wall hematoma can present with vague and easily dismissible symptoms. As such, it is important for providers to understand the differential diagnosis of postcolonoscopy complications and have a high index of suspicion for patients who may require further workup of more severe complications. Additionally, this case models a conservative approach to the management of a stable bowel wall hematoma that includes initial hospital admission for hemodynamic observation, hemoglobin monitoring, and symptom control, with close outpatient reassessment. 


\section{Statement of Ethics}

Our project was approved by our Health Sciences IRB at the University of Missouri, Columbia, MO, USA, implying that it meets medical ethical standards; patient consent was waived as information used in the case report was deidentified to our IRB specifications. Project \#2008689; review \#227169.

\section{Disclosure Statement}

We have no conflicts of interest to report.

\section{References}

1 Scholefield JH, Steele RJ, Dunlop MG, Thomas HJW, Evans GD, Eaden JA, Rutter MD, Atkin WP, Saunders BP, Lucassen A, Jenkins P, Fairclough PD, Woodhouse CRJ: Guidelines for colorectal cancer screening and surveillance in moderate and high risk groups (update from 2002). Gut 2010;59:666-689.

7 Cai S, Chen T, Yao L, et al: Management of iatrogenic colorectal perforation: from surgery to endoscopy. World J Gastrointest Endosc 2015;7:819-823.

-3 Levin TR, Zhao W, Conell C, Seeff LC, Manninen DL, Shapiro JA, et al: Complications of colonoscopy in an integrated health care delivery system. Ann Intern Med 2006;145:880-886.

-4 Rabeneck L, Paszat LF, Hilsden RJ, Saskin R, Leddin D, Grunfeld E, Wai E, Goldwasser M, Sutradhar R, Stukel TA: Bleeding and perforation after outpatient colonoscopy and their risk factors in usual clinical practice. Gastroenterology 2008;135:1899-1906.e1.

$\checkmark 5$ Ko CW, Dominitz JA: Complications of colonoscopy: magnitude and management. Gastrointest Endosc Clin N Am 2010;20:659-671.

-6 Page F, Adedeji 0: Peri-colonic haematoma following routine colonoscopy. Ann Med Surg 2016;5:97100 .

-7 Voudoukis E, et al: Intramural hematoma of the ascending colon leading to intraperitoneal hemorrhage: a possible post-polypectomy complications. Ann Gastroenterol 2012;25:265-267.

-8 Liu Y, Yang S, Tong Q: Spontaneous intramural hematoma of colon. Clin Gastroenterol Hepatol 2012;10:e38. 


\section{Case Reports in Gastroenterology

\begin{tabular}{l|l}
\hline Case Rep Gastroenterol 2017;11:599-602 \\
\hline DOI: 10.1159/000480074 & $\begin{array}{l}\text { @ } 2017 \text { The Author(s). Published by S. Karger AG, Basel } \\
\text { www.karger.com/crg }\end{array}$ \\
\hline
\end{tabular} \\ Mankoo and Kuwajima: Postpolypectomy Intramural Colonic Hematoma: The}

Conservative Management of a Potentially Fatal Complication

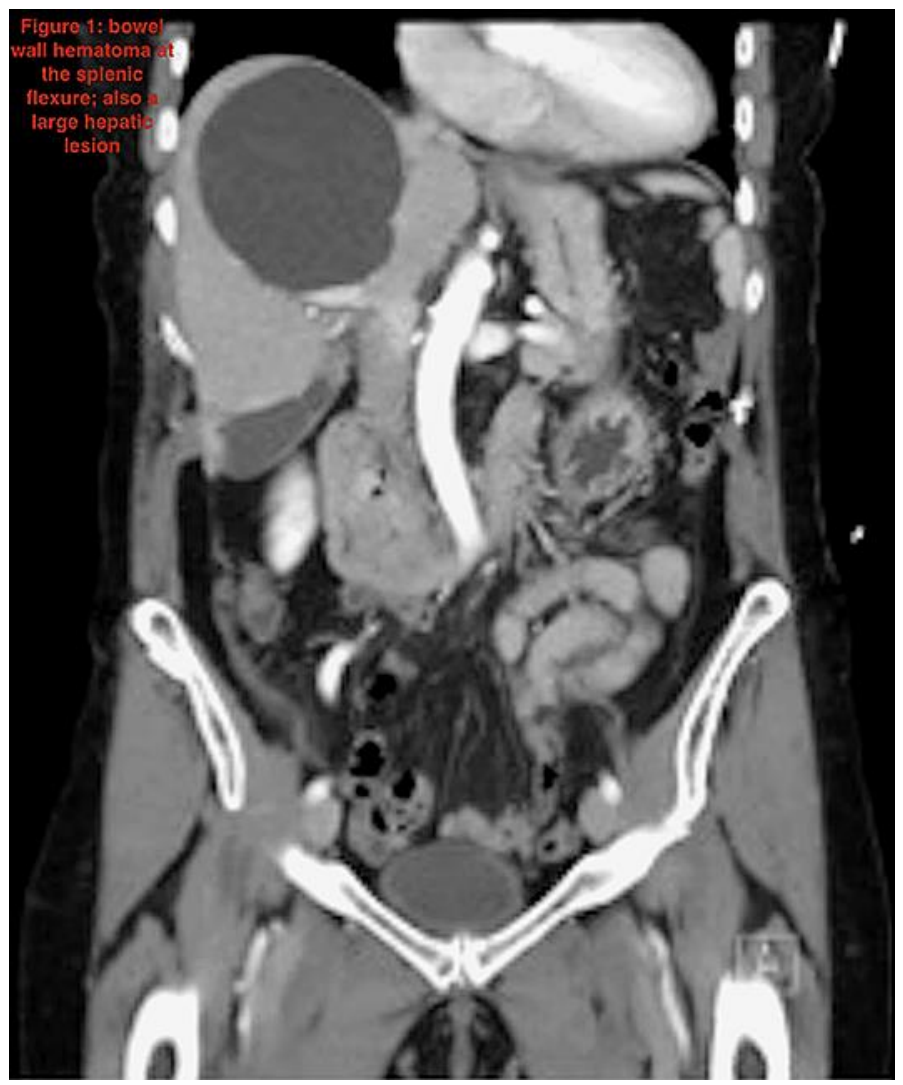

Fig. 1. Bowel wall hematoma at the splenic flexure; also a large hepatic lesion.

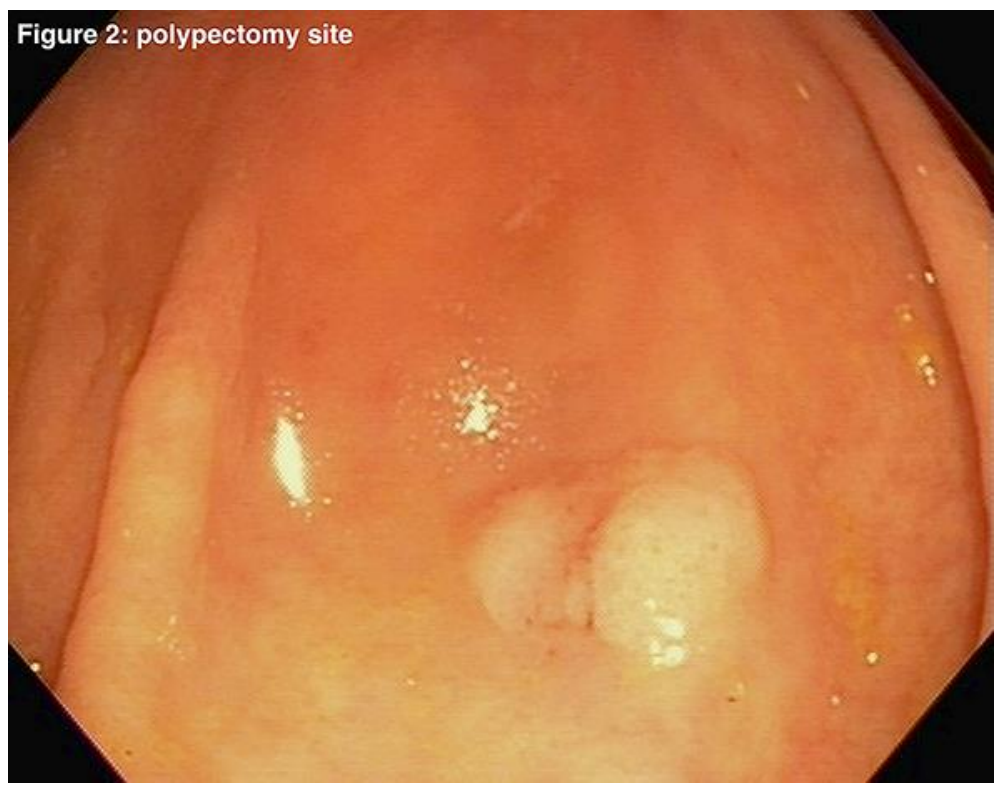

Fig. 2. Polypectomy site. 